JURNAL MATEMATIKA.STATISTIKA \& KOMPUTASI

https-//journal unhas.acid/indexphp/jmsk/index

Vol. 17, No. 2, 280-292, January, 2021

DOI: 10.20956/jmsk.v17i2.11995

\title{
Stability Analysis of a Mathematical Model in Inflammatory Response System Due to SARS Coronavirus Infection
}

\section{Analisis Kestabilan Model Matematika Sistem Respon Inflamasi Akibat Infeksi SARS Coronavirus}

\begin{abstract}
Ario Wiraya*
Abstract

Severe Acute Respiratory Syndrome (SARS) Coronavirus infection in a human body indicated by cytokine response due to an inflammation. The purpose of this research is to construct and analyze a mathematical model of interaction between inflammatory pro-response and anti-response cytokine to predict the dynamic on inflammatory response system, so that the treatment can be optimized. The results obtained in this research describe some dynamics which happen on the cytokines, i.e. the disease-free equilibrium point is asymptotically stable when the basic reproduction number is less than one. In this condition, a patient with initial concentrations of the cytokines around the disease-free equilibrium point will be free of viral infection. The infection equilibrium point is asymptotically stable when the basic reproduction number is greater than one. In this condition, a patient with initial concentrations of the cytokines around the infection equilibrium point will be infected by the virus. Probability of a patient being free of viral infection can increase if the production rate of the cytokines are decreased or the degradation rate of the cytokines are increased.
\end{abstract}

Keywords: inflammation, SARS Coronavirus, basic reproduction number.

\begin{abstract}
Abstrak
Infeksi Severe Acute Respiratory Syndrome (SARS) Coronavirus pada tubuh manusia ditandai dengan respon sitokin akibat adanya inflamasi. Tujuan penelitian ini adalah mengonstruksi dan menganalisis model matematika interaksi antara sitokin pro-respon dan anti-respon inflamasi untuk memprediksi dinamika pada sistem respon inflamasi, sehingga pengobatan dapat dioptimalkan. Hasil yang diperoleh pada penelitian ini mendeskripsikan beberapa dinamika yang terjadi pada sitokin, yaitu titik ekuilibrium bebas penyakit bersifat stabil asimtotik jika bilangan reproduksi dasar bernilai kurang dari satu. Pada kondisi ini, pasien dengan keadaan awal konsentrasi sitokin di sekitar titik ekuilibrium bebas penyakit
\end{abstract}

* Program Studi Pendidikan Matematika, Fakultas Keguruan dan Ilmu Pendidikan, Universitas Sebelas Maret,

Email: ariowiraya@staff.uns.ac.id

\section{(c) (i) 8}

This work is licensed under a Creative Commons Attribution-NonCommercial 4.0 International License 


\section{Ario Wiraya Jurnal Matematika, Statistika $\mathcal{E}$ Komputasi}

akan terbebas dari infeksi virus. Titik ekuilibrium infeksi bersifat stabil asimtotik jika bilangan reproduksi dasar bernilai lebih dari satu. Pada kondisi ini, pasien dengan keadaan awal konsentrasi sitokin di sekitar titik ekuilibrium infeksi akan terinfeksi virus. Probabilitas terbebasnya pasien dari infeksi virus dapat bertambah apabila tingkat produksi sitokin menurun atau tingkat degradasi sitokin meningkat.

Kata kunci: inflamasi, SARS Coronavirus, bilangan reproduksi dasar.

\section{PENDAHULUAN}

Severe Acute Respiratory Syndrome (SARS) Coronavirus mengalami transmisi lintas spesies dari hewan ke manusia [9], [12]. SARS Coronavirus berkembang biak pada inang alaminya, yaitu kelelawar [8], [10]. Manusia bukan merupakan inang alami dan hanya terinfeksi melalui interaksi dengan inang alaminya, baik secara langsung maupun tidak langsung melalui lingkungan, seperti menghirup kotoran inang alami atau pembawanya [22].

Imun bawaan manusia merespon infeksi virus melalui regulasi yang terdiri atas dua jenis sitokin. Sitokin jenis pertama merupakan sitokin yang merespon inflamasi, yaitu sitokin prorespon inflamasi. Sitokin jenis kedua merupakan sitokin yang menghambat respon inflamasi, yaitu sitokin anti-respon inflamasi. Respon sitokin lebih berpengaruh terhadap dampak penyakit daripada jumlah virus [11]. Infeksi virus pada manusia meningkatkan konsentrasi sitokin yang merespon inflamasi sebagai faktor yang meningkatkan keganasan penyakit [4], [6], [15], [18], [21]. Interaksi dari dua kategori sitokin tersebut memiliki peran penting dalam respon imun inflamasi [19] untuk penyakit menular [7] dan penyakit kronis autoimun [13].

Model matematika sistem respon inflamasi akibat adanya infeksi virus telah dikonstruksi pada [22]. Namun, model matematika tersebut memiliki struktur yang kompleks, sehingga analisis kestabilan titik ekuilibrium model belum dilakukan. Oleh karena itu, pada artikel ini, dikonstruksi model matematika yang lebih sederhana, sehingga analisis kestabilan titik ekuilibrium model dapat dilakukan untuk mengetahui karaketeristik sistem respon inflamasi yang berupa prediksi dinamika sitokin pro-respon dan anti-respon inflamasi di sekitar titik ekuilibrium beserta syarat kejadiannya. Hasil dari analisis tersebut dapat menjadi referensi medis untuk mengoptimalkan penanganan penyakit yang disebabkan oleh infeksi SARS Coronavirus.

\section{HASIL DAN PEMBAHASAN}

Pada bagian ini akan dipaparkan hasil yang diperoleh pada penelitian ini beserta pembahasannya. Hasil dan pembahasan tersebut disajikan dalam bentuk pemaparan metode penelitian, model matematika, titik ekuilibrium, bilangan reproduksi, analisis kestabilan, dan simulasi numerik.

\subsection{Metode Penelitian}

Penelitian ini dimulai dengan melakukan studi literatur untuk memahami interaksi antara sitokin pro-respon dengan anti-respon inflamasi akibat adanya virus. Dalam proses pemahaman tersebut, dicari faktor-faktor yang berpengaruh pada interaksi antara dua sitokin tersebut. Setelah mengetahui faktor-faktor tersebut, dilakukan pembentukan model matematika sistem respon inflamasi akibat adanya infeksi virus yang berbentuk sistem persamaan diferensial dua variabel dengan lima parameter. Dua variabel tersebut merepresentasikan konsentrasi sitokin pro-respon dan anti-respon inflamasi, sedangkan lima parameter tersebut merepresentasikan faktor-faktor yang mempengaruhi interaksi antara dua sitokin tersebut. Model matematika yang terbentuk merepresentasikan laju perubahan konsentrasi sitokin pro-respon dan anti-respon inflamasi yang 


\section{Ario Wiraya Jurnal Matematika, Statistika $\mathcal{E}$ Komputasi}

dipengaruhi oleh faktor-faktor dalam interaksinya pada sistem respon inflamasi akibat adanya infeksi virus.

Model matematika yang dikonstruksi berbentuk non-linier, sehingga analisis terhadap solusinya dilakukan secara parsial, yaitu di sekitar titik ekuilibrium model. Oleh karena itu, tahap analisis pertama yang dilakukan adalah mencari titik ekuilibrium beserta syarat eksistensinya. Selanjutnya, dilakukan pencarian bilangan reproduksi yang memerlukan koordinat titik ekuilibrium dengan menggunakan metode Matriks Generasi Berikutnya (Next Generation Matrix). Bilangan reproduksi merupakan faktor penentu terjadinya infeksi virus yang merupakan fungsi dari parameter model. Setelah itu, dilakukan analisis kestabilan terhadap titik ekuilibrium yang ditemukan. Analisis kestabilan tersebut dilakukan untuk mengetahui pola solusi di sekitar titik ekuilibrium sebagai prediksi kondisi yang akan dialami pasien beserta kriteria terjadinya kondisi tersebut yang berupa fungsi dari bilangan reproduksi. Kriteria terkena atau terbebasnya pasien dari infeksi virus berupa interval nilai bilangan reproduksi. Rekomendasi tindakan yang dapat dilakukan untuk mencegah atau mengobati infeksi virus pada pasien dapat ditentukan dengan mengatur nilai parameter yang berpengaruh pada bilangan reproduksi, sedemikian hingga bilangan reproduksi memenuhi syarat agar pasien terbebas dari infeksi virus.

Simulasi numerik dengan menggunakan software MATLAB dilakukan setelah kestabilan titik ekuilibrium dianalisis. Simulasi ini dilakukan untuk memperkuat hasil yang diperoleh pada analisis kestabilan titik ekuilibrium. Selain itu, visualisasi solusi di sekitar titik ekuilibrium dapat diketahui melalui simulasi ini. Simulasi numerik dibagi menjadi beberapa kondisi yang diperoleh dari analisis kestabilan titik ekuilibrium. Nilai parameter pada simulasi numerik diperoleh dari literatur, sedangkan nilai awal variabel ditentukan di sekitar titik ekuilibrium dihitung dengan menggunakan software MAPLE. Hasil simulasi numerik diinterpretasikan untuk memperoleh karakteristik sistem respon inflamasi akibat infeksi virus.

Berdasarkan hasil analisis yang diperoleh, dilakukan penarikan kesimpulan untuk menentukan karakteristik respon inflamasi akibat infeksi virus sebagai prediksi kondisi yang akan dialami pasien. Selain itu, dapat ditentukan rekomendasi tindakan agar pasien terbebas dari infeksi virus.

\subsection{Model Matematika}

Sistem respon inflamasi manusia terhadap infeksi SARS Coronavirus terdiri atas interaksi antara sitokin pro-respon dengan anti-respon inflamasi [22]. Inflamasi akibat adanya infeksi SARS Coronavirus direspon oleh sitokin pro-respon inflamasi untuk mengurangi dampak inflamasi. Sitokin pro-respon inflamasi diproduksi secara alami, berkurang karena berinteraksi dengan sitokin anti-respon inflamasi, dan mengalami degradasi secara alami. Sitokin anti-respon inflamasi diproduksi akibat berinteraksi dengan sitokin pro-respon inflamasi dan mengalami degradasi secara alami.

Berdasarkan interaksi yang terbentuk antara sitokin pro-respon dengan anti respon inflamasi dalam sistem respon inflamasi, didefinisikan variabel model seperti pada Tabel 1.

Tabel 1. Variabel Model

\begin{tabular}{clcc}
\hline Variabel & Interpretasi & Nilai Awal & Satuan \\
\hline $\boldsymbol{P}$ & Konsentrasi sitokin pro-respon inflamasi & Estimasi & $\mathrm{pg} / \mathrm{mL}$ \\
$\boldsymbol{A}$ & Konsentrasi sitokin anti-respon inflamasi & Estimasi & $\mathrm{pg} / \mathrm{mL}$ \\
$t$ & Waktu & Estimasi & $\mathrm{pg} / \mathrm{mL}$ \\
\hline
\end{tabular}

Variabel model bernilai non-negatif, karena menyatakan konsentrasi. Variabel model $P$ dan $A$ merupakan fungsi dari variabel $t$. Selain itu, parameter model didefinisikan pada Tabel 2. 
Ario Wiraya

Jurnal Matematika, Statistika $\mathcal{E}$ Komputasi

Tabel 2. Parameter Model

\begin{tabular}{|c|c|c|c|c|}
\hline Parameter & Interpretasi & Nilai & Satuan & Referensi \\
\hline$p_{1}$ & $\begin{array}{l}\text { Tingkat produksi } \\
\text { alami sitokin pro- } \\
\text { respon inflamasi }\end{array}$ & $\begin{array}{c}0.343 \pm 0.178 \text { atau } \\
0.81\end{array}$ & $p g / m L \cdot j a m \cdot j u m l a h$ sel & [2] \\
\hline$p_{2}$ & $\begin{array}{l}\text { Tingkat } \\
\text { penambahan } \\
\text { konsentrasi sitokin } \\
\text { anti-respon } \\
\text { inflamasi akibat } \\
\text { interaksinya } \\
\text { dengan sitokin } \\
\text { pro-respon } \\
\text { inflamasi }\end{array}$ & $\begin{array}{c}0.009 \pm 0.004 \text { atau } \\
0.81\end{array}$ & $\frac{p g}{m L \cdot j a m \cdot j u m l a h s e l}$ & {$[2]$} \\
\hline$d_{1}$ & $\begin{array}{l}\text { Tingkat } \\
\text { pengurangan } \\
\text { konsentrasi sitokin } \\
\text { pro-respon } \\
\text { inflamasi akibat } \\
\text { interaksinya } \\
\text { dengan sitokin } \\
\text { anti-respon } \\
\text { inflamasi }\end{array}$ & $0.343 \pm 0.178$ & $\frac{p g}{m L \cdot j a m \cdot j u m l a h s e l}$ & {$[2]$} \\
\hline$d_{2}$ & $\begin{array}{l}\text { Tingkat degradasi } \\
\text { alami sitokin pro- } \\
\text { respon inflamasi }\end{array}$ & $0.751 \pm 0.198$ & $j a m^{-1}$ & [2] \\
\hline$d_{3}$ & $\begin{array}{l}\text { Tingkat degradasi } \\
\text { alami sitokin anti- } \\
\text { respon inflamasi }\end{array}$ & $0.87 \pm 0.281$ & $\mathrm{jam}^{-1}$ & [2] \\
\hline
\end{tabular}

Parameter-parameter model bernilai positif, karena parameter menyatakan tingkat. Selain itu, parameter tidak bernilai nol, karena nilai nol pada parameter berarti parameter tidak memiliki pengaruh pada model. Variabel sitokin pro-respon inflamasi diasumsikan berfungsi seperti Interleukin-6 (IL-6) yang merupakan salah satu jenis sitokin pro-respon inflamasi, sedangkan variabel sitokin anti-respon inflamasi diasumsikan berfungsi seperti Interleukin-10 (IL-10) yang merupakan salah satu jenis sitokin anti-respon inflamasi. Oleh karena itu, nilai parameter interaksi antara variabel sitokin pro-respon dengan anti-respon inflamasi juga diasumsikan sama dengan nilai parameter interaksi antara IL-6 dengan IL-10.

Berdasarkan deskripsi interaksi antara sitokin pro-respon dengan anti-respon inflamasi, definisi variabel, dan parameter model yang telah disajikan, dapat dibentuk diagram kompartemen pada Gambar 1. 
Ario Wiraya

Jurnal Matematika, Statistika E Komputasi

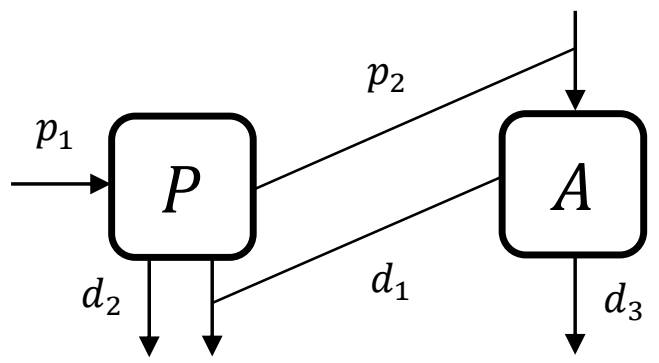

Gambar 1. Diagram Kompartemen Interaksi antara Sitokin Pro-Respon dengan Anti-Respon Inflamasi Akibat Infeksi SARS Coronavirus.

Berdasarkan diagram kompartemen yang telah dibentuk, dapat dikonstruksi model matematika sistem respon inflamasi pada manusia akibat infeksi SARS Coronavirus yang berbentuk sistem persamaan diferensial sebagai berikut.

$$
\begin{aligned}
& \frac{d P}{d t}=p_{1}-d_{1} P A-d_{2} P \\
& \frac{d A}{d t}=p_{2} P A-d_{3} A
\end{aligned}
$$

\subsection{Titik Ekuilibrium}

Titik ekuilibrium dicari dengan menyelesaikan sistem $\frac{d P}{d t}=\frac{d A}{d t}=0$ seperti pada [16], [17], [14], [20], [1]. Terdapat dua titik ekuilibrium model yang ditemukan, yaitu titik ekulibrium bebas penyakit dan titik ekuilibrium infeksi.

Teorema 1. Titik ekuilibrium bebas penyakit dari model adalah $E_{0}=\left(\frac{p_{1}}{d_{2}}, 0\right)$ yang eksis untuk setiap kondisi. Titik ekuilibrium infeksi dari model adalah $E_{i}=\left(\frac{d_{3}}{p_{2}}, \frac{p_{1} p_{2}-d_{2} d_{3}}{d_{1} d_{3}}\right)$ yang eksis apabila $\frac{p_{1} p_{2}}{d_{2} d_{3}} \geq 1$.

Bukti : Syarat diperolehnya titik ekuilibrium adalah dengan menetapkan nilai $\frac{d P}{d t}=\frac{d A}{d t}=0$. Berdasarkan penetapan ini, diperoleh

$$
\begin{array}{r}
p_{1}-d_{1} P A-d_{2} P=0 \\
p_{2} P A-d_{3} A=0
\end{array}
$$

Berdasarkan Persamaan (3), diperoleh $A=0$ atau $P=\frac{d_{3}}{p_{2}}$. Selanjutnya, dengan mensubstitusikan $A=0$ ke Persamaan (2) diperoleh $P=\frac{p_{1}}{d_{2}}$. Berdasarkan hal ini diperoleh titik ekuilibrium

$$
E_{0}=\left(\frac{p_{1}}{d_{2}}, 0\right) \text {. }
$$

Titik ekuilibrium ini eksis untuk setiap kondisi, karena nilai $\frac{p_{1}}{d_{2}}>0$. Titik ekuilibrium ini disebut titik ekuilibrium bebas penyakit, karena konsentrasi sitokin anti-respon inflamasi bernilai nol. Hal ini inflamasi yang terjadi akibat infeksi virus dapat teratasi oleh sitokin pro-respon inflamasi tanpa adanya hambatan dari sitokin anti-respon inflamasi.

Kemudian, dengan mensubstitusikan $P=\frac{d_{3}}{p_{2}}$ ke Persamaan (2) diperoleh $A=\frac{p_{1} p_{2}-d_{2} d_{3}}{d_{1} d_{3}}$. Akibatnya, diperoleh titik ekuilibrium 


\section{Ario Wiraya \\ Jurnal Matematika, Statistika \& Komputasi}

$$
E_{i}=\left(\frac{d_{3}}{p_{2}}, \frac{p_{1} p_{2}-d_{2} d_{3}}{d_{1} d_{3}}\right)
$$

Titik ekuilibrium ini eksis jika $p_{1} p_{2}-d_{2} d_{3}>0$ yang ekuivalen dengan $\frac{p_{1} p_{2}}{d_{2} d_{3}}>1$. Titik ekuilibrium ini disebut titik ekuilibrium infeksi, karena konsentrasi sitokin anti-respon inflamasi bernilai positif. Hal ini berarti fungsi sitokin pro-respon inflamasi dalam mengatasi inflamasi akibat infeksi virus mengalami hambatan dari sitokin anti-respon inflamasi.

\subsection{Bilangan Reproduksi Dasar $\left(R_{0}\right)$}

Bilangan reproduksi dasar digunakan sebagai faktor penentu penyebaran penyakit dalam suatu populasi. Dalam hal ini, bilangan reproduksi dasar menjadi parameter yang digunakan untuk mengukur potensi infeksi virus dalam suatu individu.

Teorema 2. Bilangan reproduksi dasar dari Sistem (1) adalah $R_{0}=\frac{p_{1} p_{2}}{d_{2} d_{3}}$.

Bukti : Bilangan reproduksi dasar dari Sistem (1) dicari dengan menggunakan metode Matriks Generasi Berikutnya (Next Generation Matrix) [3]. Matriks Generasi Berikutnya dapat diperoleh dari kelas $A$. Kelas $A$ dapat dituliskan sebagai berikut.

$$
A(t)=\alpha(P, A)-\beta(P, A),
$$

dengan

$$
\alpha(P, A)=\left[p_{2} P A\right] \operatorname{dan} \beta(P, A)=\left[d_{3} P A\right] .
$$

Selanjutnya, secara berturut-turut dilakukan linearisasi fungsi $\alpha$ dan $\beta$ terhadap variabel $A$, diperoleh

$$
\gamma=p_{2} P \text { dan } \varphi=d_{3} .
$$

Misalkan Matriks Generasi Berikutnya dinotasikan dengan $H$, maka

$$
H=\gamma \varphi^{-1}=\left(p_{2} P\right)\left(d_{3}\right)^{-1}=\frac{p_{2} P}{d_{3}} .
$$

Kemudian, dengan mensubstitusikan nilai absis dan ordinat pada titik ekuilibrium bebas penyakit $E_{0}=\left(\frac{p_{1}}{d_{2}}, 0\right)$ ke Persamaan (4), diperoleh

$$
H=\frac{p_{2}\left(\frac{p_{1}}{d_{2}}\right)}{d_{3}}=\frac{p_{1} p_{2}}{d_{2} d_{3}}=R_{0} .
$$

Nilai $R_{0}=\frac{p_{1} p_{2}}{d_{2} d_{3}}$ merupakan bilangan reproduksi dasar dari Sistem (1).

Pada Teorema 1 bagian pencarian syarat eksistensi titik ekuilibrium infeksi $E_{i}$, diperoleh syarat eksistensi titik ekuilibrium infeksi $E_{i}$ adalah $\frac{p_{1} p_{2}}{d_{2} d_{3}}>1$, sedangkan nilai $R_{0}=\frac{p_{1} p_{2}}{d_{2} d_{3}}$. Oleh karena itu, syarat eksistensi titik ekuilibrium infeksi $E_{i}$ tersebut ekuivalen dengan $R_{0}>1$. Berdasarkan hal ini, diperoleh keterkaitan syarat eksistensi titik ekuilibrium infeksi $E_{i}$ dengan $R_{0}$, yaitu titik ekuilibrium infeksi $E_{i}$ eksis jika $R_{0}>1$.

\subsection{Analisis Kestabilan}

Dinamika solusi di sekitar titik ekuilibrium dapat diketahui melalui analisis kestabilan titik ekuilibrium. Kestabilan titik ekulilibrium dicari dengan metode linearisasi model seperti pada [5].

Teorema 3. Jika $R_{0}<1$, maka titik ekuilibrium bebas penyakit $E_{0}$ bersifat stabil asimtotik (star node). Jika $R_{0}>1$, maka titik ekuilibrium bebas penyakit $E_{0}$ bersifat tidak stabil (saddle). Didefinisikan $D=\left(d_{2} R_{0}\right)^{2}-4 d_{2} d_{3}\left(R_{0}-1\right)$. Sifat kestabilan titik ekuilibrium infeksi $E_{i}$ dapat dibagi menjadi beberapa kondisi sebagai berikut.

1. Jika $D \geq 0$ dan $R_{0}>1$, maka $E_{i}$ bersifat stabil asimtotik (star node). 


\section{Jurnal Matematika, Statistika $\mathcal{E}$ Komputasi}

2. Jika $D<0$ dan $R_{0}>1$, maka $E_{i}$ bersifat stabil asimtotik (spiral).

Bukti : Matriks Jacobian dari Sistem (1) di titik $(P, A)$ adalah

$$
J(P, A)=\left[\begin{array}{cc}
-d_{1} A-d_{2} & -d_{1} P \\
p_{2} A & p_{2} P-d_{3}
\end{array}\right] .
$$

Berdasarkan matriks Jacobian pada Persamaan (5), diperoleh matriks Jacobian di titik ekuilibrium bebas penyakit $E_{0}=\left(\frac{p_{1}}{d_{2}}, 0\right)$ adalah

$$
J\left(\frac{p_{1}}{d_{2}}, 0\right)=\left[\begin{array}{cc}
-d_{2} & -\frac{p_{1} d_{1}}{d_{2}} \\
0 & \frac{p_{1} p_{2}}{d_{2}}-d_{3}
\end{array}\right]
$$

Misalkan $\lambda$ adalah nilai eigen dari matriks Jacobian pada Persamaan (6) dan $I$ adalah matriks identitas berukuran $2 \times 2$, maka persamaan $\left|\lambda I-J\left(\frac{p_{1}}{d_{2}}, 0\right)\right|=0$ akan menghasilkan persamaan karakteristik

$$
\left(\lambda+d_{2}\right)\left(\lambda+\frac{p_{1} p_{2}-d_{2} d_{3}}{d_{2}}\right)=0
$$

Akar-akar dari Persamaan (7) adalah $\lambda_{1}=-d_{2}<0$ dan $\lambda_{2}=\frac{p_{1} p_{2}-d_{2} d_{3}}{d_{2}}=d_{3}\left(R_{0}-1\right)$. Jika nilai $R_{0}<1$, maka $\lambda_{2}<0$. Akibatnya, jika $R_{0}<1$, maka titik ekuilibrium bebas penyakit $E_{0}$ bersifat stabil asimtotik (star node). Selain itu, jika nilai $R_{0}>1$, maka $\lambda_{2}>0$. Akibatnya, jika $R_{0}>1$, maka titik ekuilibrium bebas penyakit $E_{0}$ bersifat tidak stabil (saddle).

Berdasarkan matriks Jacobian pada Persamaan (4), diperoleh matriks Jacobian di titik ekuilibrium infeksi $E_{i}=\left(\frac{d_{3}}{p_{2}}, \frac{p_{1} p_{2}-d_{2} d_{3}}{d_{1} d_{3}}\right)$ adalah

$$
J\left(\frac{d_{3}}{p_{2}}, \frac{p_{1} p_{2}-d_{2} d_{3}}{d_{1} d_{3}}\right)=\left[\begin{array}{cc}
\frac{-p_{1} p_{2}}{d_{3}} & -\frac{d_{1} d_{3}}{p_{2}} \\
\frac{p_{2}\left(p_{1} p_{2}-d_{2} d_{3}\right)}{d_{1} d_{3}} & 0
\end{array}\right] .
$$

Persamaan $\left|\lambda I-J\left(\frac{d_{3}}{p_{2}}, \frac{p_{1} p_{2}-d_{2} d_{3}}{d_{1} d_{3}}\right)\right|=0$ akan menghasilkan persamaan karakteristik

yang ekuivalen dengan

$$
\lambda^{2}+\left(\frac{p_{1} p_{2}}{d_{3}}\right) \lambda+\left(p_{1} p_{2}-d_{2} d_{3}\right)=0
$$

$$
\lambda^{2}+\left(d_{2} R_{0}\right) \lambda+\left[d_{2} d_{3}\left(R_{0}-1\right)\right]=0
$$

Akar-akar dari karakteristik tersebut adalah

$$
\lambda_{1}=\frac{-d_{2} R_{0}+\sqrt{\left(d_{2} R_{0}\right)^{2}+4\left[d_{2} d_{3}\left(1-R_{0}\right)\right]}}{2} \text { dan } \lambda_{2}=\frac{-d_{2} R_{0}-\sqrt{\left(d_{2} R_{0}\right)^{2}+4\left[d_{2} d_{3}\left(1-R_{0}\right)\right]}}{2} .
$$

Selanjutnya, didefinisikan $D=\left(d_{2} R_{0}\right)^{2}+4\left[d_{2} d_{3}\left(1-R_{0}\right)\right]$, sehingga diperoleh

$$
\lambda_{1}=\frac{-d_{2} R_{0}+\sqrt{D}}{2} \text { dan } \lambda_{2}=\frac{-d_{2} R_{0}-\sqrt{D}}{2} \text {. }
$$

Bentuk $D$ pada nilai $\lambda_{1}$ dan $\lambda_{2}$ yang disajikan pada Persamaan (8) memiliki beberapa kemungkinan nilai yang menentukan sifat kestabilan titik ekuilibrium infeksi $E_{i}$. Oleh karena itu, penyelidikan kestabilan titik ekuilibrium infeksi $E_{i}$ dibagi menjadi beberapa kondisi, yaitu :

1. Pada kondisi $\frac{R_{o}-1}{R_{o}^{2}}=\frac{d_{2}}{4 d_{3}}$ jika dan hanya jika $D=0$, untuk kasus $R_{0}<1$, nilai $\frac{R_{o}-1}{R_{o}{ }^{2}}<0$, sedangkan nilai $\frac{d_{2}}{4 d_{3}}>0$. Akibatnya, $\frac{R_{O}-1}{R_{o}^{2}}<\frac{d_{2}}{4 d_{3}}$, sehingga kondisi $\frac{R_{o}-1}{R_{o}^{2}}=\frac{d_{2}}{4 d_{3}}$ tidak dipenuhi. 


\section{Ario Wiraya}

\section{Jurnal Matematika, Statistika $\mathcal{E}$ Komputasi}

Untuk kasus $R_{0}=1$, nilai $\frac{R_{O}-1}{R_{o}{ }^{2}}=0$, sedangkan nilai $\frac{d_{2}}{4 d_{3}}>0$. Akibatnya, $\frac{R_{o}-1}{R_{o}{ }^{2}}<\frac{d_{2}}{4 d_{3}}$, sehingga kondisi $\frac{R_{0}-1}{R_{o}{ }^{2}}=\frac{d_{2}}{4 d_{3}}$ tidak dipenuhi. Untuk kasus $R_{0}>1$, nilai $\frac{R_{o}-1}{R_{o}{ }^{2}}>0$ dan nilai $\frac{d_{2}}{4 d_{3}}>0$. Akibatnya, kondisi $\frac{R_{o}-1}{R_{o}{ }^{2}}=\frac{d_{2}}{4 d_{3}}$ dapat dipenuhi. Oleh karena itu, haruslah $R_{0}>1$. Nilai $R_{0}>1$ mengakibatkan nilai $\lambda_{1}=\lambda_{2}=\frac{-d_{2} R_{0}}{2}<0$. Akibatnya, diperoleh titik ekuilibrium infeksi $E_{i}$ bersifat stabil asimtotik (star node). Pada kondisi $\frac{R_{o}-1}{R_{o}{ }^{2}}<\frac{d_{2}}{4 d_{3}}$ jika dan hanya jika $D>0$, untuk kasus $R_{0}<1$, titik ekuilibrium infeksi $E_{i}$ tidak eksis. Untuk kasus $R_{0}=1$, diperoleh nilai $\lambda_{1}=0$ dan $\lambda_{2}<0$. Akibatnya, titik ekuilibrium infeksi $E_{i}$ merupakan titik ekuilibrium nonhiperbolik [16], sehingga sifat kestabilannya tidak dapat diselidiki dengan metode linearisasi (kasus ini dijadikan permasalahan terbuka). Untuk kasus $R_{0}>1$, nilai $\frac{R_{o}-1}{R_{o}{ }^{2}}>0$ dan nilai $\frac{d_{2}}{4 d_{3}}>0$. Akibatnya, kondisi $\frac{R_{0}-1}{R_{o}{ }^{2}}<\frac{d_{2}}{4 d_{3}}$ dapat dipenuhi. Oleh karena itu, haruslah $R_{0}>1$. Nilai $R_{0}>1$ mengakibatkan nilai $\lambda_{1}, \lambda_{2}<0$. Akibatnya, titik ekuilibrium infeksi $E_{i}$ bersifat stabil asimtotik (star node). Akibatnya, jika $D \geq 0$ dan $R_{0}>1$, titik ekuilibrium infeksi $E_{i}$ bersifat stabil asimtotik (star node).

2. Pada kondisi $\frac{R_{o}-1}{R_{o}{ }^{2}}>\frac{d_{2}}{4 d_{3}}$ jika dan hanya jika $D<0$, untuk kasus $R_{0}<1$, nilai $\frac{R_{O}-1}{R_{o}{ }^{2}}<0$, sedangkan nilai $\frac{d_{2}}{4 d_{3}}>0$. Akibatnya, $\frac{R_{o}-1}{R_{O}^{2}}<\frac{d_{2}}{4 d_{3}}$, sehingga kondisi $\frac{R_{o}-1}{R_{o}{ }^{2}}>\frac{d_{2}}{4 d_{3}}$ tidak dipenuhi. Untuk kasus $R_{0}=1$, nilai $\frac{R_{o}-1}{R_{o}{ }^{2}}=0$, sedangkan nilai $\frac{d_{2}}{4 d_{3}}>0$. Akibatnya, $\frac{R_{o}-1}{R_{o}{ }^{2}}<\frac{d_{2}}{4 d_{3}}$, sehingga kondisi $\frac{R_{o}-1}{R_{o}{ }^{2}}>\frac{d_{2}}{4 d_{3}}$ tidak dipenuhi. Untuk kasus $R_{0}>1$, nilai $\frac{R_{o}-1}{R_{o}{ }^{2}}>0$ dan nilai $\frac{d_{2}}{4 d_{3}}>0$. Akibatnya, kondisi $\frac{R_{O}-1}{R_{O}{ }^{2}}>\frac{d_{2}}{4 d_{3}}$ dapat dipenuhi. Oleh karena itu, haruslah $R_{0}>1$. Berdasarkan hal ini, diperoleh nilai $\lambda_{1}, \lambda_{2} \in \mathbb{C}$, dengan $\lambda_{1}=\frac{-d_{2} R_{0}}{2}+\frac{\sqrt{4\left[d_{2} d_{3}\left(R_{0}-1\right)\right]-\left(d_{2} R_{0}\right)^{2}}}{2} i$ dan $\lambda_{1}=$ $\frac{-d_{2} R_{0}}{2}-\frac{\sqrt{4\left[d_{2} d_{3}\left(R_{0}-1\right)\right]-\left(d_{2} R_{0}\right)^{2}}}{2} i$. Berdasarkan nilai $\lambda_{1}$ dan $\lambda_{2}$, diperoleh nilai $\operatorname{Re}\left(\lambda_{1}\right)=$ $\operatorname{Re}\left(\lambda_{2}\right)=\frac{-d_{2} R_{0}}{2}<0$. Oleh karena itu, titik ekuilibrium infeksi $E_{i}$ bersifat stabil asimtotik (spiral node).

\subsection{Simulasi Numerik}

Simulasi numerik dilakukan untuk mengidentifikasi solusi sistem di sekitar titik ekuilibrium bebas penyakit dan infeksi secara visual. Solusi yang disimulasikan merupakan solusi pada nilai parameter yang memenuhi kondisi-kondisi kestabilan. Oleh karena itu, simulasi numerik juga dilakukan untuk memperkuat hasil analisis kestabilan titik ekuilibrium.

Simulasi numerik dibagi menjadi dua kasus berdasarkan nilai $R_{0}$ yang diperoleh pada analisis kestabilan. Nilai parameter ditetapkan sedemikian hingga berada di dalam interval yang telah dituliskan pada Tabel 2 dan memenuhi kondisi kestabilan. Nilai parameter tersebut disajikan pada Tabel 3.

Tabel 3. Nilai Parameter Model pada Simulasi Numerik

\section{Nilai}

Parameter

Kasus $R_{0}<1 \quad$ Kasus $R_{0}>1$

$p_{1} 0.343$

$0.81 \quad 0.81$


Ario Wiraya

Jurnal Matematika, Statistika $\mathcal{E}$ Komputasi

\begin{tabular}{lccc}
\hline $\boldsymbol{p}_{\mathbf{2}}$ & 0.009 & 0.81 & 0.81 \\
$\boldsymbol{d}_{\mathbf{1}}$ & 0.343 & 0.343 & 0.343 \\
$\boldsymbol{d}_{\mathbf{2}}$ & 0.751 & 0.751 & 0.553 \\
$\boldsymbol{d}_{\mathbf{3}}$ & 0.87 & 0.87 & 0.589 \\
\hline
\end{tabular}

Acuan nilai awal variabel pada kedua kasus diperoleh dengan mensubstitusikan nilai parameter pada Tabel 3 ke formula titik ekuilibrium bebas penyakit $E_{0}$ dan infeksi $E_{i}$. Perhitungan acuan nilai awal dilakukan dengan menggunakan software MAPLE dengan pembulatan tiga angka di belakang koma. Acuan nilai awal disajikan pada Tabel 4. Nilai awal untuk setiap kasus dipilih di sekitar acuan nilai awal.

Tabel 4. Acuan Nilai Awal pada Simulasi Numerik

\begin{tabular}{cccc} 
Nilai Awal di & \multicolumn{3}{c}{ Nilai } \\
\cline { 2 - 4 } $\begin{array}{l}\text { Sekitar Titik } \\
\text { Ekuilibrium }\end{array}$ & Kasus $\boldsymbol{R}_{\mathbf{0}}<\mathbf{1}$ & \multicolumn{2}{c}{ Kasus $\boldsymbol{R}_{\mathbf{0}}>\mathbf{1}$} \\
\cline { 2 - 4 } & $(0.457,0)$ & $(1.079,0)$ & $\boldsymbol{D}<\mathbf{0}$ \\
\hline Bebas penyakit $\boldsymbol{E}_{\mathbf{0}}$ & Tidak eksis & $(1.074,0.009)$ & $(0.727,1.635)$ \\
Infeksi $\boldsymbol{E}_{\boldsymbol{i}}$ & &
\end{tabular}

Simulasi numerik solusi-solusi Sistem (1) di sekitar titik ekuilibrium bebas penyakit $E_{0}$ dan infeksi $E_{i}$ pada kedua kasus dilakukan dengan menggunakan software MATLAB.

\subsubsection{Kasus $R_{0}<1$}

Pada kasus ini, nilai $R_{0}=0.004724734835<1$. Dinamika solusi Sistem (1) yang memenuhi kondisi pada kasus ini disajikan pada Gambar 2.

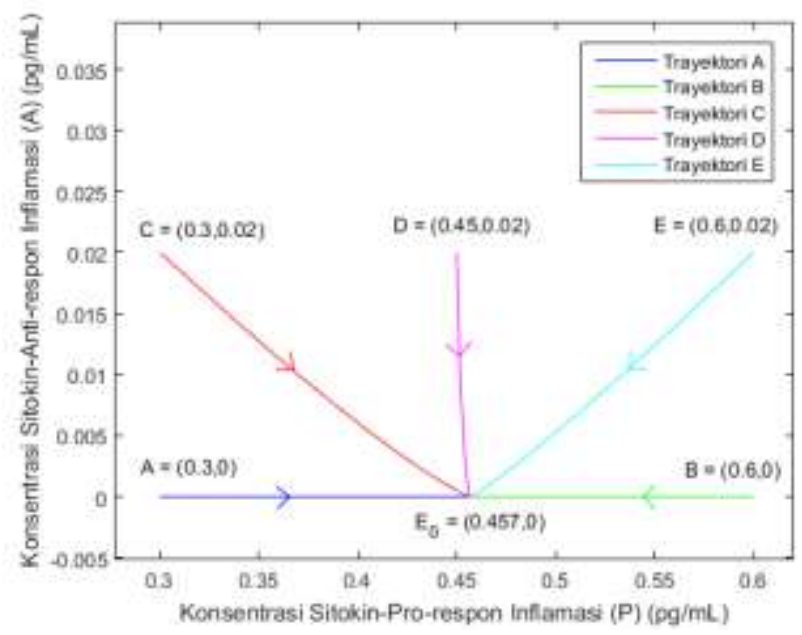

Jika

Gambar 2. Potret Fase Solusi Sistem (1) di Sekitar $E_{0}$ pada kasus $R_{0}<1$.

penyakit $E_{0}$ bersifat stabil asimtotik (star node) dan titik ekuilibrium infeksi $E_{i}$ tidak eksis. Hal ini berarti jika bilangan reproduksi dasar bernilai kurang dari satu atau rasio tingkat produksi alami dengan tingkat degradasi alami sitokin pro-respon inflamasi lebih kecil daripada rasio tingkat degradasi alami dan tingkat penambahan konsentrasi sitokin anti-respon inflamasi akibat interaksinya dengan sitokin pro-respon inflamasi, maka pasien dengan konsentrasi awal sitokin 
Ario Wiraya

Jurnal Matematika, Statistika E Komputasi

pro-respon dan anti-respon inflamasi di sekitar titik ekuilibrium bebas penyakit $E_{0}$ akan terbebas dari infeksi virus.

\subsubsection{Kasus $R_{0}>1$}

Kasus ini dibagi menjadi dua subkasus yaitu $D \geq 0$ dan $D<0$.

\subsubsection{Subkasus $D \geq 0$}

Pada subkasus ini, nilai $D=0.5578040187>0$ dan $R_{0}=1.004178337>1$. Dinamika solusi Sistem (1) yang memenuhi kondisi pada kasus ini disajikan pada Gambar 3.

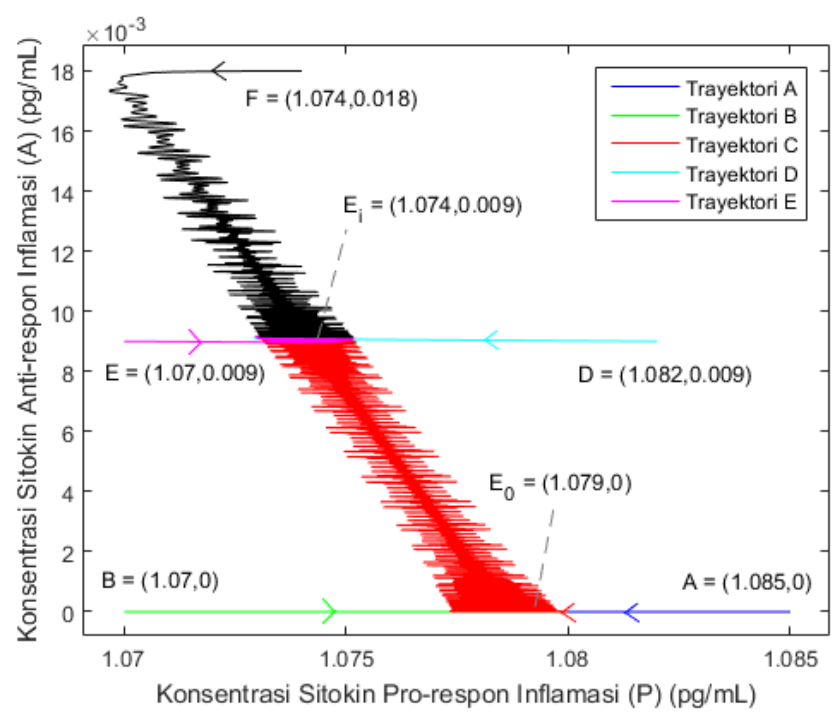

(a)

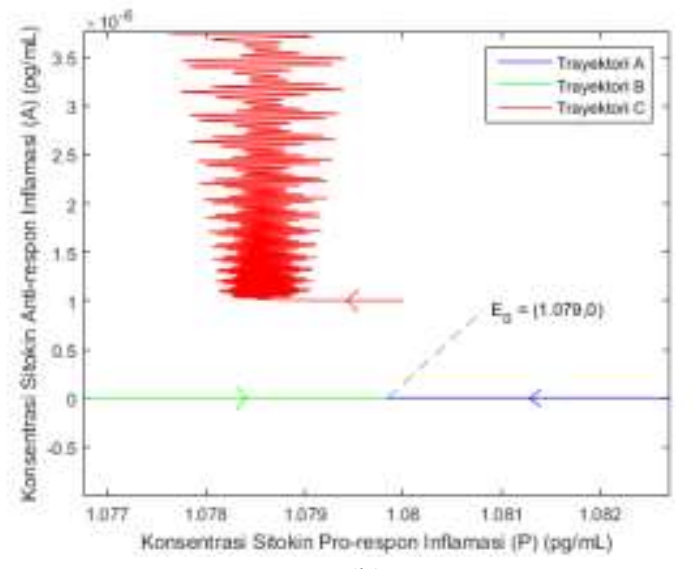

(b)

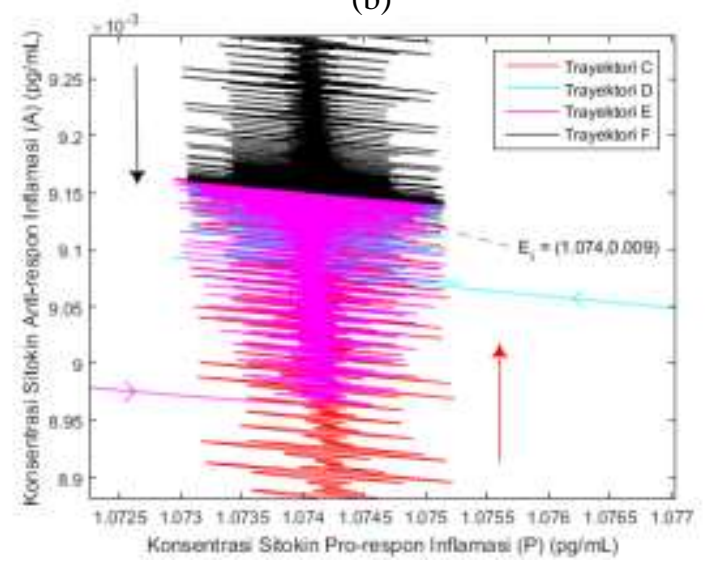

(c)

Gambar 3. (a) Potret Fase Solusi Sistem (1) di Sekitar $E_{0}$ dan $E_{i}$ pada kasus $R_{0}>1$ dan $D \geq 0$. (b) Perbesaran Potret Fase Solusi Sistem (1) di Sekitar $E_{0}$. (c) Perbesaran Potret Fase Solusi Sistem (1) di Sekitar $E_{i}$.

L.o.L.L. suokasus $\boldsymbol{\nu}<\boldsymbol{U}$

Pada subkasus ini, nilai $D=-0.080709997<0$ dan $R_{0}=2.014325319>1$. Dinamika solusi Sistem (1) yang memenuhi kondisi pada kasus ini disajikan pada Gambar 4. 


\section{Ario Wiraya \\ Jurnal Matematika, Statistika \& Komputasi}

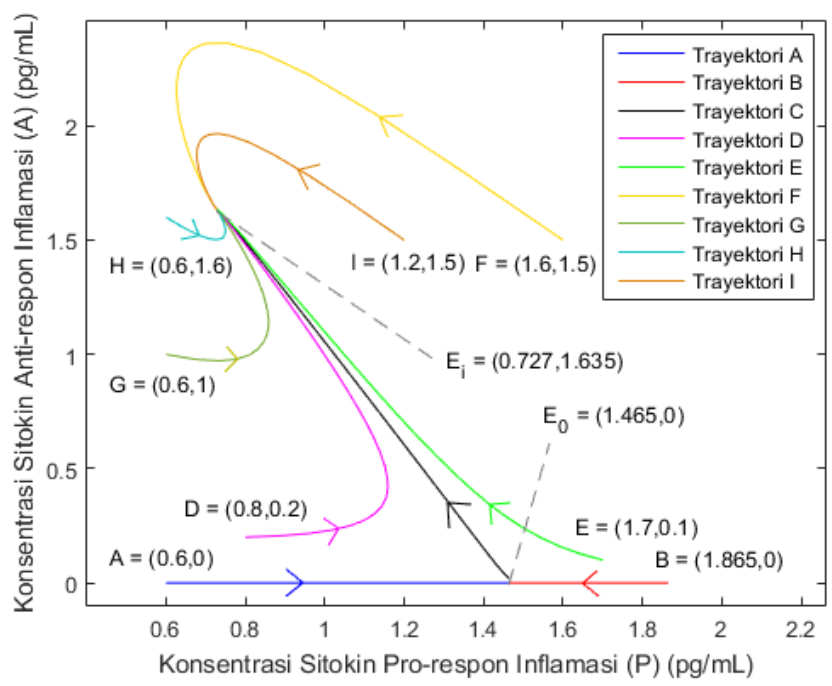

(a)

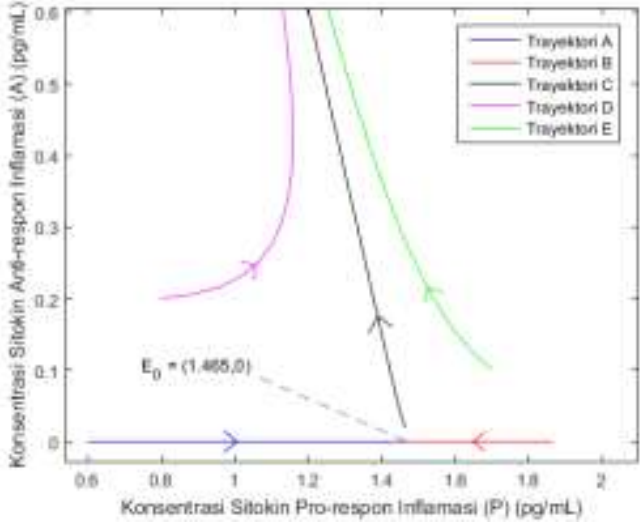

(b)

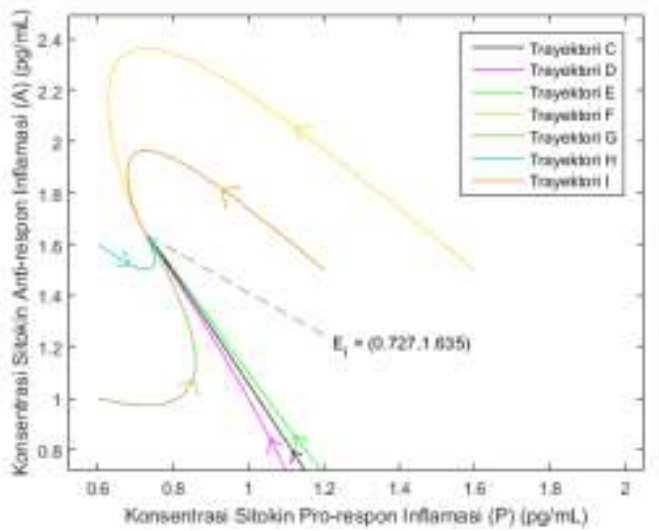

(c)

Gambar 4. (a) Potret Fase Solusi Sistem (1) di Sekitar $E_{0}$ dan $E_{i}$ pada kasus $R_{0}>1$ dan $D<0$. (b) Perbesaran Potret Fase Solusi Sistem (1) di Sekitar $E_{0}$. (c) Perbesaran Potret Fase Solusi Sistem (1) di Sekitar $E_{i}$.

Jika $R_{0}>1$ yang ekuivalen dengan $\frac{p_{1} p_{2}}{d_{2} d_{3}}>1$ atau $\frac{p_{1}}{d_{2}}>\frac{d_{3}}{p_{2}}$, maka titik ekuilibrium bebas penyakit $E_{0}$ bersifat tidak stabil (saddle) dan titik ekuilibrium infeksi $E_{i}$ bersifat stabil asimtotik (dapat berupa star node atau spiral node). Hal ini berarti jika bilangan reproduksi dasar bernilai lebih dari satu atau rasio tingkat produksi alami dengan tingkat degradasi alami sitokin pro-respon inflamasi lebih besar daripada rasio tingkat degradasi alami dan tingkat penambahan konsentrasi sitokin anti-respon inflamasi akibat interaksinya dengan sitokin pro-respon inflamasi, maka pasien dengan konsentrasi awal sitokin pro-respon dan anti-respon inflamasi di sekitar titik ekuilibrium infeksi $E_{i}$ akan terkena infeksi virus. Selain itu, terdapat dua kemungkinan kondisi yang akan terjadi pada pasien dengan konsentrasi sitokin pro-respon dan anti-respon inflamasi di sekitar titik ekuilibrium bebas penyakit $E_{0}$. Pertama, pasien dapat terbebas dari infeksi virus apabila konsentrasi awal sitokin pro-respon dan anti-respon inflamasi berada pada manifold stabil dari solusi sistem. Kedua, pasien dapat terkena infeksi virus apabila konsentrasi awal sitokin prorespon dan anti-respon inflamasi berada pada manifold tidak stabil dari solusi sistem. 


\section{Ario Wiraya \\ Jurnal Matematika, Statistika $\mathcal{E}$ Komputasi}

\section{KESIMPULAN}

Terdapat beberapa karakteristik pada interaksi sitokin pro-respon dengan anti-respon inflamasi akibat infeksi SARS Coronavirus yang dapat digunakan sebagai prediksi kondisi yang akan dialami pasien. Karakteristik tersebut bergantung pada nilai bilangan reproduksi dasar $R_{0}$. Jika $R_{0}<1$ yang ekuivalen dengan rasio tingkat produksi alami dengan tingkat degradasi alami sitokin pro-respon inflamasi lebih kecil daripada rasio tingkat degradasi alami dan tingkat penambahan konsentrasi sitokin anti-respon inflamasi akibat interaksinya dengan sitokin pro-respon inflamasi, maka pasien dengan konsentrasi awal sitokin pro-respon dan anti-respon inflamasi di sekitar titik ekuilibrium bebas penyakit $E_{0}$ akan terbebas dari infeksi virus. Jika $R_{0}>1$ yang ekuivalen dengan rasio tingkat produksi alami dengan tingkat degradasi alami sitokin pro-respon inflamasi lebih besar daripada rasio tingkat degradasi alami dan tingkat penambahan konsentrasi sitokin anti-respon inflamasi akibat interaksinya dengan sitokin pro-respon inflamasi, maka pasien dengan konsentrasi awal sitokin pro-respon dan anti-respon inflamasi di sekitar titik ekuilibrium infeksi $E_{i}$ akan terinfeksi virus. Selain itu, terdapat dua kemungkinan kondisi yang akan terjadi pada pasien dengan konsentrasi sitokin pro-respon dan anti-respon inflamasi di sekitar titik ekuilibrium bebas penyakit $E_{0}$. Kemungkinan pertama adalah pasien dapat terbebas dari infeksi virus apabila konsentrasi awal sitokin pro-respon dan anti-respon inflamasi berada pada manifold stabil dari solusi sistem. Kemungkinan kedua yaitu pasien dapat terinfeksi virus apabila konsentrasi awal sitokin pro-respon dan anti-respon inflamasi berada pada manifold tidak stabil dari solusi sistem.

Probabilitas terbebasnya pasien dari infeksi SARS Coronavirus dapat meningkat apabila

dilakukan upaya agar $R_{0}=\frac{p_{1} p_{2}}{d_{2} d_{3}}$ bernilai kurang dari satu, sehingga pasien dengan konsentrasi awal sitokin pro-respon dan anti-respon inflamasi di sekitar titik ekuilibrium bebas penyakit $E_{0}$ dapat terbebas dari infeksi virus. Upaya pertama adalah memperkecil tingkat produksi alami sitokin pro-respon inflamasi $\left(p_{1}\right)$ atau tingkat penambahan konsentrasi sitokin anti-respon inflamasi akibat interaksinya dengan sitokin pro-respon inflamasi $\left(p_{2}\right)$. Upaya kedua adalah memperbesar tingkat degradasi alami sitokin pro-respon inflamasi $\left(d_{2}\right)$ atau tingkat degradasi alami sitokin anti-respon inflamasi $\left(d_{3}\right)$. Upaya optimal dapat dilakukan dengan melakukan kedua upaya tersebut secara bersamaan.

\section{DAFTAR PUSTAKA}

[1] Aprilyani, L. D. S., Kasbawati, \& Toaha, S., 2020. Analisis Kestabilan Model Matematika Infeksi Penyakit HIV dengan Pengaruh Terapi Antiretroviral. Jurnal Matematika, Statistika, \& Komputasi, Vol. 17, No. 1, 109-116.

[2] Brady, R., Frank-Ito, D. O., Tran, H. T., Janum, S., Moller, K., Brix., S., Ottesen, J. T., Mehlsen, J. \& Olufsen, M. S., 2018. Personalized Mathematical Model of EndotoxinInduced Inflammatory Responses in Young Men and Associated Changes in Heart Rate Variability. Math. Model. Nat. Phenom., Vol. 13, No. 5, 1-20.

[3] Driessche, P.V.D. \& Watmough, J., 2002. Reproduction Numbers and Sub-threshold Endemic Equilibria for Compartmental Models of Disease Transmission. Mathematical Biosciences, Vol. 180, 29-48.

[4] Frieman, M., Heise, M. \& Baric, R., 2008. SARS Coronavirus and Innate Immunity. Virus Res., Vol. 133, No. 1, 101-112.

[5] Hale, J. K. \& Kocak, H. 1991. Dynamics and Bifurcations, Third Edition. Springer-Verlag, New York.

[6] He, D., Zhang, C., He, X., Shen, W., Li, H. \& Zhao, G., 2006. Expression of Elevated Levels of Pro-inflammatory Cytokines in SARS-CoV-Infected ACE2+ Cells in SARS 


\section{Ario Wiraya Jurnal Matematika, Statistika \& Komputasi}

Patients: Relation to the Acute Lung Injury and Pathogenesis of SARS. J. Pathol., Vol. 210, No. 3, 288-297.

[7] Henderson, B., Seymour, R. \& Wilson, M., 1998. The Cytokine Network in Infectious Disease. EOS, Vol. 18, 7-14.

[8] Hu, B., Ge, X., Wang, L.-F. \& Shi, Z., 2015. Bat Origin of Human Coronaviruses. Virol. J., Vol. 12, 221.

[9] Jones, K. E., Patel, N. G., Levy, M. A., Storeygard, A., Balk, D., Gittleman, J. L. \& Daszak, P., 2008. Global Trends in Emerging Infectious Diseases. Nature, Vol. 451, No. 7181, 990993.

[10] Li, W., Shi, Z., Yu, M., Ren, W., Smith, C., Epstein, J. H.., Wang, H., Crameri, G., Hu, Z. \& Zhang, H., 2005. Bats are Natural Reservoirs of SARS-like Coronaviruses. Science, Vol. 310, No. 5748, 676-679.

[11] Liu, Q., Zhou Y.-H. \& Yang, Z.-Q., 2016. The Cytokine Storm of Severe Influenza and Development of Immunomodulatory Therapy. Cell. Mol. Immunol., Vol. 13, No. 1, 3-10.

[12] Lloyd-Smith, J. O., George, D., Pepin, K. M., Pitzer, V. E., Pulliam, J. R., Dobson, A. P., Hudson, P. J. \& Grenfell, B. T., 2009. Epidemic Dynamics at the Human-Animal Interface. Science, Vol. 326, No. 5958, 1362-1367.

[13] McInnes, I. \& Schett, G., 2007. Cytokines in the Pathogenesis of Rheumatoid Arthritis. Nat Rev. Immunol., Vol. 7, No. 6, 429-442.

[14] Nursamsi, Toaha, S. \& Kasbawati, 2020. Analisis Kestabilan Model Penyebaran Penyakit Tuberkulosis pada Penderita Diabetes Mellitus dengan Faktor Pengobatan. Jurnal Matematika, Statistika, \& Komputasi, Vol. 17, No. 1, 50-60.

[15] Peiris, J. S. M., Cheung, C. Y., Leung, C . Y. H. \& Nicholls, J. M., 2009. Innate Immune Responses to Influenza A H5N1: Friend or Foe? Trends Immunol., Vol. 30, No. 12, 574584.

[16] Perko, L. 2001. Differential Equations and Dynamical System, Third Edition. SpringerVerlag, New York.

[17] Prawandani, N., Toaha, S. \& Kasbawati, 2020. Model Matematika VSEIR Penyebaran Penyakit Antraks pada Populasi Hewan dengan Efek Vaksinasi dan Pengobatan. Jurnal Matematika, Statistika, \& Komputasi, Vol. 17, No. 1, 14-25.

[18] Safronetz, D., Zivcec, M., Lacasse, R., Feldmann, F., Rosenke, R., Long, D., Haddock, E., Brining, D., Gardner, D. \& Feldmann, H., 2011. Pathogenesis and Host Response in Syrian Hamsters following Intranasal Infection with Andes Virus. PloS Pathog., Vol. 7, No. 12, e1002426.

[19] Seymour, R. \& Henderson, B., 2001. Pro-Inflammatory-Anti-Inflammatory Cytokine Dynamics Mediated by Cytokine-Receptor Dynamics in Monocytes. Math. Med. Biol., Vol. 18, No. 2, 159-192.

[20] Sulma, Toaha, S. \& Kasbawati, 2020. Analisis Kestabilan Model Matematika Dinamika Penyebaran Penyakit Meningitis dengan pengaruh Vaksinasi, Kampanye, dan Pengobatan. Jurnal Matematika, Statistika, \& Komputasi, Vol. 17, No. 1, 71-81.

[21] Szretter, K., Gangappa, S., Lu, X., Smith, C., Shieh, W.-J., Zaki, S., Sambhara, S., Tumpey, T. \& Katz, J., 2007. Role of Host Cytokine Responses in the Pathogenesis of Avian H5N1 Influenza Viruses in Mice. J. Virol., Vol. 81, No. 6, 2736-2744.

[22] Zhang, W., Jang, S., Jonsson, C. B. \& Allen, L. J. S., 2018. Models of Cytokine Dynamics in the Inflammatory Response of Viral Zoonotic Infectious Diseases. Mathematical Medicine and Biology: A Journal of the IMA, Vol. 36, No. 3, 269-295. 